\title{
National Environmental Data Facilities and Services of the Czech Republic and Their Use in Environmental Economics
}

\author{
Jana Soukopová ${ }^{1}$, Jiří Hřebíček ${ }^{2}$, and Jiří Valta ${ }^{3}$ \\ ${ }^{1}$ Faculty of Economics and Administration, Masaryk University \\ Lipová 507/41a, 60200 Brno, Czech Republic \\ soukopova@econ.muni.cz \\ ${ }^{2}$ Institute of Biostatistics and Analyses, Masaryk University, \\ Kamenice 126/3, 62500 Brno, Czech Republic \\ hrebicek@iba.muni.cz \\ ${ }^{3}$ Czech Environmental Information Agency, Vršovická 1442/65 \\ 10010 Prague 10, Czech Republic \\ jiri.valta@cenia.cz
}

\begin{abstract}
National environmental data facilities and services are part of the environmental information systems of the Ministry of the Environment of the Czech Republic that have been under development since 1990. In 2010 the development of the National Information System for Collecting and Evaluating Information on Environmental Pollution project started, co-financed by the European Regional Development Fund. This project consists of an integrated system of reporting (ISPOP), an environmental help desk (EnviHELP), and the national INSPIRE geoportal, which were developed between 2010 and 2013 and were discussed at ISESS 2013. This paper introduces the current development of several national environmental and financial data facilities and services based on eGovernment implementation in the Czech Republic and the open environmental and financial data approach of the Czech Ministry of the Environment and the Czech Ministry of Finance. It also introduces the web information system that enabled us to find the relationship between environmental economics and municipal waste management in the Czech Republic.
\end{abstract}

Keywords: environmental data, information system, environmental services, eGovernment, open government data, environmental economics.

\section{Introduction}

The development of eGovernment is part of the current strategy for the modernisation of public administration in the Czech Republic which was approved in July 2007: "Efficient Public Administration and Friendly Public Services - Strategy on Realisation of Smart Administration in the Period 2007-2015" (further "Smart Administration Strategy"). The overall purpose of this policy instrument is for the Public Administration (PA) to achieve effectiveness comparable to that of the European Union (EU) and its 
Member States. The "Strategic Framework of the Development of eGovernment 2014+" further develops the Smart Administration Strategy and outlines steps and measures to be taken to enhance electronic governance, to improve and upgrade its architecture, to secure its financing, and to transform it into a standard information and communication technology (ICT) tool used by all PAs in their everyday communication with their clients - the public, representatives of the business sector, and other subjects [1]. The construction of environmental data facilities and infrastructure focuses primarily on the transparent disclosure of data created during these processes. In 2013, the Ministry of the Interior (MoI) of the Czech Republic adopted the "Strategic Framework for the Development of eGovernment 2014+", which regards eGovernment as an interactive process involving PA authorities, i.e., national, regional, and municipal governments, as well as citizens, entrepreneurs, and other stakeholders. The activities of the MoI in eGovernment are connected with the information agendas of the Ministry of the Environment (MoE) and their registration in the Register of Rights and Obligations of the Basic Public Administration Registers of eGovernment [2] which have been in place since 1 July 2012. These agendas are a cornerstone of the eGovernment of the Czech Republic. Their basic objective is to help citizens, companies, and other entities that come into contact with PA by minimizing the number of their personal visits to government offices through the use of ICT tools with on-line access from anywhere, at any time. At the same time, the agendas require that the PA must perform a safe, efficient, and transparent exchange of accurate and up-todate environmental data [3].

The strategic approach to the development of national environmental data facilities and services focuses on a high level of eEnvironment services [4] and on building support for MoE information services. The approach enables a broader effectiveness of MoE policy instruments for environmental protection. The basis for such changes is the management of the organizational framework and strategy of ICT resources, support, and services. The Environmental Information Systems (EISs) of the MoE manage the processing, retrieval, and presentation of environmental data and information, in support of the Aarhus Convention [5], [7].

In the Czech Republic there are currently about 40 different EISs in operation, including a geographic information system in compliance with INSPIRE standards [6] and several thousand environmental databases [3]. Most of these information resources are directly available to the general public, regardless of the applicability of their content.

The notification of the scope to national environmental data and services (agendas) in eGovernment of the Czech Republic has now finished [2]. This notification ensured the legitimacy of access to environmental data through the information system of the Basic Public Administration Registers of eGovernment. The information flow within the EISs of the MoE has been formalized with the necessary degree of ICT infrastructure. These EISs are reflected in the new concept of the Information Strategy of MoE [7], whose attestation took place in November 2012 [8].The PA currently publishes environmental and related data mostly through prepared EIS applications. However, these applications only suit a certain type of user. Users wishing to use the environmental data in a different manner than that intended by the PA are excluded. Data that 
users might want that is not published by the PA include: tenders and budgets; payments made by individual towns, cities, regions, and national institutions; and the composition of municipal representation and the individual votes of its members [9].

Various third-party developers can create many applications that display, analyse, and link the data in ways that may be interesting to the public. For example, applications can be created that show: trends in the numbers and amounts of tenders in individual regions; trends in municipal budgets in individual regions; tender-winning companies that are led by municipal representatives; and the ten biggest suppliers for each regional city.

Most of the necessary data for environmental economic modelling is produced from taxpayers' money [9] and collected by the PA information systems. The related data is even often available on the PA websites, such as those of the MoI, MoE, the Ministry of Finance (MoF), the Ministry of Regional Development (MoRD), and the Czech Statistical Office (CZSO). However, due to the way this data is published, the creation of smart custom applications is challenging for the future development of eGovernment in the Czech Republic, both financially and in terms of time [1].

In section 2 of the paper, we present our experience with the standard means of collecting environmental data through the Integrated System of Reporting (ISPOP) [10], which enables open public access to nationwide data for several EISs. It provides environmental data in a form that allows access to anyone at any time and freely allows the data to be combined. In section 3 of the paper we discuss our experience with the open data infrastructure of the MoF, which enables public access to financial data through its MONITOR web information system [25] and with the ROZPOČETOBCE [11, 12] system, which enables the comparison of financial data for every municipality in the Czech Republic in a time series. Further discussion in section 3 is devoted to our experience in creating software applications [27] for the environmental economic modelling that the public really needs.

\section{National Environmental Data Facilities and Services of Public Administration}

\subsection{Collection of Environmental and Financial Data}

Environmental legislation of the Czech Republic is in compliance with the European Union (EU) and requires organizations, companies, enterprises, etc. (i.e. environmental reporters) to provide the PA with information on the environmental impact of their activities. Their environmental reports and the duty of notification are defined by the relevant Czech environmental legislation, which obliges environmental reporters to keep prescribed records and report them to the PA of environmental protection.

The duty of environmental reporters is to deliver relevant environmental data, information, and messages to the PA authorities and institutions concerned. Legal provisions exist to control the reporting obligation. Environmental reports include primary environmental data such as air, water, and soil pollution, the generation and treatment of waste, electrical and electronic waste, etc. Most of these reports are 
processed by the Czech Environmental Information Agency (CENIA) [8] through the Integrated System of Reporting (ISPOP) [10] of the MoE, which was developed in collaboration with Telefonica O2 CR between 2008 and 2013. ISPOP was constructed to ensure flexibility in terms of its expansion to other environmental reporting agendas and to ensure compliance with updated environmental legislative obligations [8]. The hardware architecture of ISPOP consists of the IBM server eCenter BladeCenter, HS 22, and IBM disc array storage System Storage DS3400. Communication infrastructure is based on Cisco network elements. The software architecture consists of several modules: VMware virtualization; Novell SUSE Linux operating system; Jboss and Tomcat application servers; Oracle 11g database and ISPOP application layer (own J2EE application); CMS Magnolia (presentation); Adobe LiveCycle ES2 (operation with PDF form); Novell eDirectory (identification); and Novell Access Gateway (SSO).

The basic idea of ISPOP is a form solution in the information technology of Adobe LiveCycle ES. Electronic smart forms are available in PDF format and are part of the XML layer for computer processing [13]. The forms also include a PDF layer for an electronic signature, by means of which it is possible to authorize a document. Filling in the forms and browsing through them is possible with Adobe Reader.

Standardized PDF forms enable: obtaining and storing structured content (XML according to the valid XSD template); editing forms in Adobe Reader; online checking and sending reports to ISPOP; online submission to ISPOP Data Storage; content encoding forms into 2D bar codes.

The main technical requirement for using ISPOP is the ability to connect to the Internet, at least for the amount of time necessary for receiving/being assigned to the environmental report. A user needs an internet browser with the additional free software of Adobe Reader to work with ISPOP web applications.

ISPOP built the universal input data gateway of several EISs, providing incoming data files in a specified standardized format and the control and distribution of target processing systems. ISPOP enables the management of reports submitted using the environmental record form and the archiving and evaluation of their content (in cooperation with other related systems of eGovernment).

The Central System of State Accounting Information (CSÚIS) [28] of the MoF is designed to gather the accounting records of selected entities (accounting units, e.g. all municipalities in the Czech Republic) for the operational management of the MoF. It collects only the prescribed obligatory forms with financial data, which responsible persons submit in the automatically encrypted XML files using the Simple Object Access Protocol (SOAP) interface (the preferred option) or manually using the CSÚIS web application or the application of the batch statements. It is a similar collection method to that of the collection of environmental data through ISPOP.

\subsection{Public Access to Environmental and Financial Data}

The web information system EnviHELP [14] provides support for a particular operating state of ISPOP, e.g. administration for incumbents fulfilling reporting obligations under Act No. 25/2008 Coll., as well as business communities and the general public in providing environmental information in relation to Act No. 123/1998 Coll., on public access to environmental information and the Aarhus convention. 
Many EISs have been developed in the Czech Republic in the past decade, but only some collect environmental data through ISPOP with standardized interactive PDF forms.

Data standards [13] for reporting through ISPOP are published every year by the MoE, where for any legislative obligation there is a data standard (in XSD format) and a detailed description (in PDF format). These data standards describe the data structures, the data formats and the automated checks of the content of the submitted information. Forms are available in the accounts of registered environmental reporters after login into the ISPOP system. Here is a brief description of two EISs using prescribed data standards:

- Integrated Pollution Register (IRZ), [16], in compliance with the Pollutant Release and Transfer Register (PRTR), is an environmental database or inventory of potentially hazardous chemical substances and/or pollutants released to the air, water, or soil and transferred off-site for treatment or disposal according to the OECD Council Recommendation [17]. IRZ is a publicly accessible database of plants for which the amount of pollution produced beyond the legal limits has been reported. The system records 93 different pollutants of every plant monitored in all types of releases and transfers, according to the established threshold, which is reported as the amount of a substance in kilograms per calendar year.

- Information system of waste management (ISOH) [18] is a publicly accessible database containing data on the waste generation and treatment by generators and data on facilities for treatment, recovery, and disposal of waste. The system records annual reports of more than 70,000 different generators in all 6,500 municipalities and more 3,000 facilities. The annual ISOH database contains more than 50,000 records of municipal waste generation and 10,000 records about their treatment. The nationwide database VISOH [19], which contains the aggregated data of ISOH, is accessible to the general public. The nationwide database ALLISOH [20], which contains all of the data of ISOH, is accessible for the staff of the State administration in environment protection.

MONITOR [25] is a specialized web information portal of the MoF that allows open public access to budget and accounting information from all levels of the PA. MONITOR also provides the financial statements of all PA units. The presented information comes from the Integrated Information System of the Treasury (IISSP) [25] of the MoF and CSUIS, and they are updated quarterly.

The primary version of MONITOR was released in May 2013. It replaced the previous MoF web information portals ARIS [23] (database of municipalities' accounting from 2000 to 2009) and ÚFIS [24] (database of municipalities' accounting from 2010 to 2012). In December 2013 the analytical part of portal was made available, which allows dynamic data analysis using advanced tools for financial reporting.

Unfortunately, other transparently published data by the PA in the eGovernment services are not in a proprietary format (only scanned to PDF or manually created tables). They are not published with standardized open formats that would allow the general public to: share the data freely and combine the data freely. 


\section{Case Study: Environmental Economic Model and Information System of Municipal Waste Management}

We developed environmental economic models and information systems [21, 22] for all types of waste treatment facilities: mechanical biological treatment plants, incineration plants with energy recovery and landfills, composting and biogas plants, and sorting plants. We wanted to use a time series to investigate municipal waste management and financial data. We used municipal waste management data from ISOH with the collaboration of the CENIA agency and the MoE for the time series 20082013.

We also needed a time series of municipal financial data. We tried to use the publicly accessible data from the web portals ARIS, ÚFIS, and MONITOR of the MoF. However, they do not provide simple tools for downloading publicly accessible data like the systems VISOH for the public or ALLISOH for the PA.

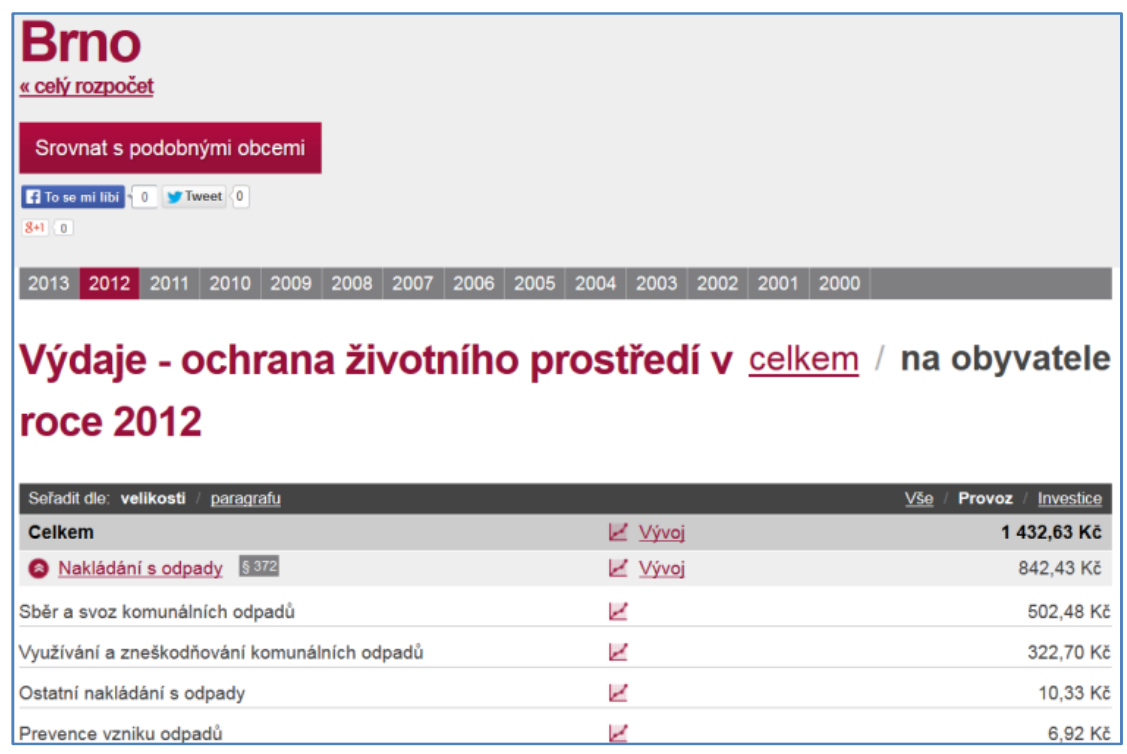

Fig. 1. Public expenditure on waste management per capita in Czech crowns [Kč] in the city of Brno in 2012

It is very difficult to find an appropriate time series of financial data of a given municipality. Therefore, we analysed the database structures of ARIS and UFIS. One student developed the web information system ROZPOČETOBCE [11, 12] in 2012 and updated it in 2013. ROZPOČETOBCE enables the presentation of publicly accessible financial data (public income and expenditure) of every municipality in the Czech Republic in the period from 2000 to 2013 from many different viewpoints. Every citizen and user of this smart web system can analyse complete public incomes 
and expenditures of a municipality in the Czech Republic. We chose the city of Brno as an example; see Figs. 2 and 3 where per capita expenditures in municipal waste management are presented. The expenditure of municipal waste management in the municipalities covers the costs associated with the collection, pick-up, transportation, use, disposal, other treatment, and prevention of municipal waste (Fig. 2).

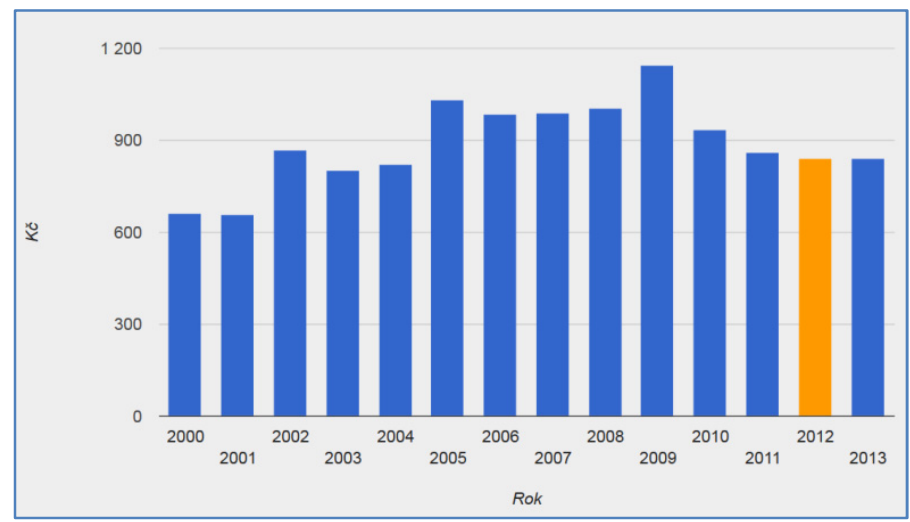

Fig. 2. Graph of per capita public expenditure on waste management in Czech crowns [Kč] in the city of Brno 2000-2013

In environmental economic models and information systems [21, 22], we also used publicly accessible data from the Information System on Public Procurement and RISY [26] of the MoRD, where we had to develop a special parser to download the required municipal data.

We continued, on the basis of the ROZPOČETOBCE system, to create a new information system [27] for the automatic visualization of public incomes and expenditures in waste management of all municipalities, districts, and regions with the use of a time series of publicly accessible data from the VISOH and ALLISOH of the MoE, ARIS, ÚFIS and MONITOR of the MoF, and RISY of the MoRD web information systems. The new complete database system has more than 15 million records.

One of the outputs of the new system [27] covers the expenditure and revenue of municipalities on waste management, the generation of waste in municipalities, and the cost of landfill waste, including their aggregation with respect to the number of municipal inhabitants. For data analysis in the system [27], we used a mathematicalstatistical theory of sets and a cluster analysis of each municipality. We sorted municipalities into groups (sets) according to population. For the nine resulting groups of municipalities we compared the data on the average per capita expenditure, the maximum and minimum value of per capita expenditure, and the standard deviation of expenditure and per capita data for the entire file with the set of all municipalities in the Czech Republic; see Table 1. 
Table 1. Total per capita expenditure on waste management for municipalities in the Czech Republic in 2012

\begin{tabular}{rrrrr}
\hline \multicolumn{1}{l}{ Population } & $\begin{array}{c}\text { Number of } \\
\text { municipalities }\end{array}$ & $\begin{array}{c}\text { Total of } \\
\text { inhabitants }\end{array}$ & \multicolumn{2}{c}{$\begin{array}{c}\text { Expenditure per capita in } \\
\text { Czech crowns [Kč] }\end{array}$} \\
\cline { 5 - 6 }$\leq 500$ & 3,464 & 835,971 & 862.81 & $\begin{array}{c}\text { Average } \\
\text { Standard } \\
\text { deviation }\end{array}$ \\
\hline $501-1,000$ & 1,352 & 953,662 & 830.16 & 465.81 \\
$1,001-4,000$ & 1,047 & $1,917,991$ & 962.38 & 807.25 \\
$4,001-10,000$ & 198 & $1,210,408$ & 968.83 & 493.9 \\
$10,001-20,000$ & 62 & 871,834 & 964.31 & 419.7 \\
$20,001-50,000$ & 41 & $1,167,522$ & 987.91 & 423.16 \\
$50,001-100,000$ & 16 & $1,137,171$ & 854.52 & 173.68 \\
$100,001-1,000,000$ & 4 & 947,894 & 693.50 & 209.61 \\
$>1,000,000$ & 1 & $1,241,664$ & $1,097.70$ & 0 \\
\hline
\end{tabular}

The information from Table 1 would be appropriate to add to the analytical tools of the MONITOR system so that a municipality could compare its own expenses with that of other municipalities (e.g., according to their position in the district or region, by size category, etc.) and thus uncover potential methods for reducing costs and increasing efficiency in waste management.

\section{Conclusion}

All of the PA information systems in the Czech Republic that are accessible through the web interface have similar shortcomings. Legislation in the Czech Republic has presented no centralized way to constitute and fully fulfil public data access following Directive 2003/98/EC, known as the "PSI Directive", as announced in the Smart Administration Strategy. Each Ministry created its own information system or database system, which have been in closed forms. The exception is the MoE strategy [7], which had its own format and application of EIS dependent on standardized data. The applicability of other PA information systems is difficult. For the user, this means prevented or restricted work with the data of the PA. Current social, technological, and economic changes create challenges and new expectations for national environmental data facilities and services based on ISPOP. Given that these challenges are largely intertwined, any vision for the future of public data services needs to take a multi-disciplinary approach. One solution may be embracing open government data, based on the principles of collaboration, transparency, and participation within an appropriate governance framework. Such an open government model of national data facilities and services builds on open data, open services and open decisions. 
Acknowledgement. This research was supported by the Czech Science Foundation (GACR) under the project "Unfair competition and other economic factors influencing the efficiency of the provision of public services".

\section{References}

1. Action 42 in Czech Republic, http: / / www. egovap-evaluation.eu/ indicator.php?id_country=5\&action_n=42

2. Základní registry veřejnésprávy (Basic public administration registers), http: / /www.mvcr.cz/clanek/ zakladni-registry-zakladni-registry-verejne-spravy.aspx

3. Hřebíček, J., Kubásek, M.: Environmental information systems (in Czech). AkademickénakladatelstvíCERM, Brno (2011), http://www.iba.muni.cz/res/file/ucebnice/hrebicekenvironmentalni-informacni-systemy.paf

4. Hřebíček, J., Pillmann, W.: eEnvironment: Reality and challenges for eEnvironment implementation in europe. In: Hřebíček, J., Schimak, G., Denzer, R. (eds.) Environmental Software Systems. IFIP AICT, vol. 359, pp. 1-14. Springer, Heidelberg (2011)

5. Århus Convention, http: / / ec. europa.eu/environment/aarhus /

6. INSPIRE standards, http://geostandards.geonovum.nl/index.php/1.3.3_INSPIRE

7. Information strategy of the Ministry of Environment (in Czech), http: / / www.mzp.cz/cz/informacni_strategie

8. Prášek, J., Valta, J., Hřebíček, J.: National INSPIRE Geoportal of the Czech Republic. In: Hřebíček, J., Schimak, G., Kubásek, M., Rizzoli, A.E. (eds.) ISESS 2013. IFIP AICT, vol. 413, pp. 425-438. Springer, Heidelberg (2013), doi:10.1007/978-3-642-41151-9_40.

9. Soukopová, J., Malý, I., Hřebíček, J., Struk, M.: Decision Support of Waste Management Expenditures Efficiency Assessment. In: Hřebíček, J., Schimak, G., Kubásek, M., Rizzoli, A.E. (eds.) ISESS 2013. IFIP AICT, vol. 413, pp. 651-660. Springer, Heidelberg (2013), doi:10.1007/978-3-642-41151-9_61.

10. ISPOP - Integrated System of Reporting, http : / /www . ispop. cz

11. Řezác, K.: Web portal for the evaluation of public municipal budgets (in Czech). Master thesis, Masaryk University, Brno (2012)

12. Rozpočetobce, http://www.rozpocetobce.cz/

13. Data standards, https://www.ispop.cz/magnoliaPublic/cenia-project/ uvod/datove_standardy_aktualne.html

14. EnviHELP - Environmental help desk, http://helpdesk. cenia.cz

15. INSPIRE geoportal, http://inspire-geoportal.ec.europa.eu/

16. Integrated register pollution, http://www.irz.cz/

17. Recommendation of the Council on Implementing Pollutant Release and Transfer Registers (PRTRs),

http: / /acts. oecd.org/Instruments / ShowInstrumentView. aspx? Ins trument $I D=44 \&$ Lang $=e n \& B o o k=F a l s e$

18. ISOH - Waste Management Information System, http: / /www1.cenia.cz/www/odpady/isoh

19. VISOH - Public Waste Management Information System of the Ministry of the Environment, http://isoh.cenia.cz/groupisoh

20. ALLISOH, http://isoh.cenia.cz/allisoh/login.php?mes=sesexpired 
21. Soukopová, J., Hřebíček, J.: Model of cost and price relationships for municipal waste management of the Czech Republic. Acta Univ. Agric. et Silvic. Mendel. Brun. 59, 371-378 (2011)

22. Hřebíček, J., Kalina, J., Soukopová, J.: Integrated economic model of waste management: Case study for South Moravia region. Acta Univ. Agric. et silvic. Mendel. Brun. 61, 917-922 (2013)

23. ARIS-Automatized budget information system, http://wwwinfo.mfcr.cz/aris/

24. UFIS - Monitoring of municipal finances, http://wwwinfo.mfcr.cz/ufis/

25. MONITOR, http://monitor.statnipokladna.cz/en/2014/

26. RIS - Regional Information Service, http: / /www.risy.cz/en/

27. Kuttner, M.: Web portal for the evaluation of the cost of waste management for municipalities, districts and regions. Master thesis. Masaryk University, Brno (2014) (in Czech).

28. CSÚIS - Central system accounting information of state, http: / / www.statnipokladna.cz/cs/csuis/zakladni-popis

29. IISSP - Integrated information system of Treasury, http: / /www.statnipokladna.cz/cs / o-statni-pokladne/integrovany-informacni-system-statni-pok 